\title{
Het hart kent zijn geheimen
}

Citation for published version (APA):

Hermens, W. T. (1997). Het hart kent zijn geheimen. Drukkerij Spons.

https://doi.org/10.26481/spe.19971010wh

Document status and date:

Published: 10/10/1997

DOI:

10.26481/spe.19971010wh

Document Version:

Publisher's PDF, also known as Version of record

\section{Please check the document version of this publication:}

- A submitted manuscript is the version of the article upon submission and before peer-review. There can be important differences between the submitted version and the official published version of record.

People interested in the research are advised to contact the author for the final version of the publication, or visit the DOI to the publisher's website.

- The final author version and the galley proof are versions of the publication after peer review.

- The final published version features the final layout of the paper including the volume, issue and page numbers.

Link to publication

\footnotetext{
General rights rights.

- You may freely distribute the URL identifying the publication in the public portal. please follow below link for the End User Agreement:

www.umlib.nl/taverne-license

Take down policy

If you believe that this document breaches copyright please contact us at:

repository@maastrichtuniversity.nl

providing details and we will investigate your claim.
}

Copyright and moral rights for the publications made accessible in the public portal are retained by the authors and/or other copyright owners and it is a condition of accessing publications that users recognise and abide by the legal requirements associated with these

- Users may download and print one copy of any publication from the public portal for the purpose of private study or research.

- You may not further distribute the material or use it for any profit-making activity or commercial gain

If the publication is distributed under the terms of Article $25 \mathrm{fa}$ of the Dutch Copyright Act, indicated by the "Taverne" license above, 
Universiteitsbibliotheek

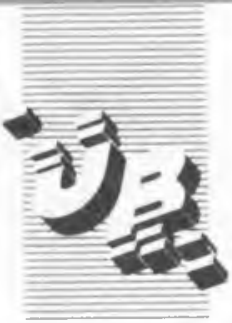

De uitleentermijn verstrijkt op:

$-9$
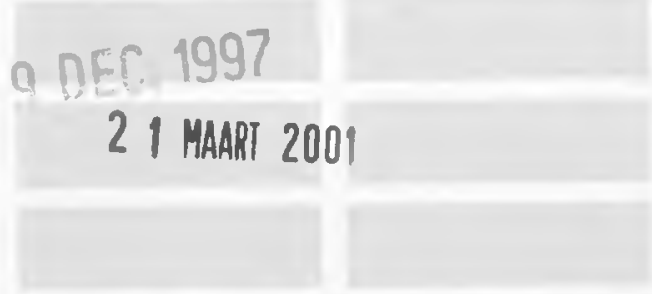

- 8 แก! 2002

-8 NNY. 2002

Universiteit Maastricht

Postbus 616

6200 MD Maastricht
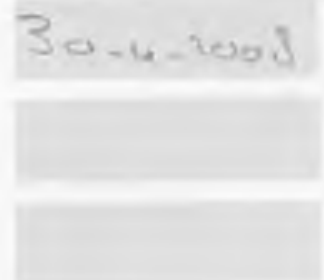

Gelieve deze publicatie tijdig te retourneren of (telefonisch) verlenging van de uitleentermijn aan te vragen.

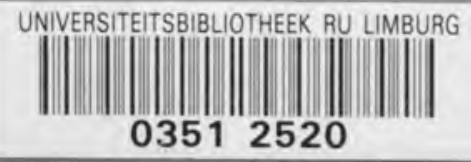


HET HART KENT ZIIN GEHEIMEN. 
"Le coeur a ses raisons, que la raison ne connait point."

\author{
Blaise Pascal.
}


Het hart kent zijn geheimen

Rede, uitgesproken bij de aanvaarding van het ambt van bijzonder hoogleraar in de Moleculaire Fysica aan de Universiteit Maastricht op 10 Oktober 1997.

door

Dr. W. Th. Hermens.

Drukkerij Spons, Eijsden 


\section{Inhoud}

Inleiding.

Wetenschap en paradigma.

Waarom men de grootte van een hartinfarct wil meten.

De vele oorzaken van celdood.

De infarctgrootte gemeten met markeer-eiwitten.

Conclusies.

Dankwoord.

Literatur

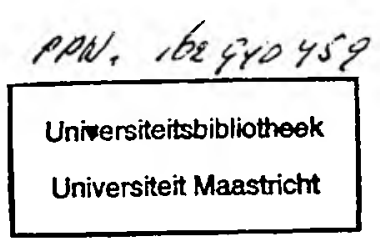


Mijnheer de Rector Magnificus

Zeer gewaardeerde toehoorders

Volgens het universitaire reglement is het voornaamste doel van een inaugurele reden een toelichting te geven op het vakgebied, en wel in voor iedereen verstaanbare taal. Nu lijkt men zich als fysicus daarbij in een comfortabele positie te bevinden want de fysica, of natuurkunde, houdt zich met bijna alles bezig, van het ontstaan van het heelal tot de veiligheid van uw ijskast. Maar wat comfortabel lijkt, is dat niet altijd. Een te grote stoel geeft rugklachten en zelfs de beperking tot de moleculaire natuurkunde kan hier niet veel helpen. Anders dan bij de 'moleculaire biologie', die in feite alleen de verwerking van erfelijke informatie bestudeert, omvat de moleculaire fysica alle natuurkundige aspecten van moleculen en atomen. Bepaalde onderdelen daarban, zoals de eigenschappen van gasmengsels, zijn al in de vorige eeuw bestudeerd door onderzoekers als Boltzmann, Gibbs, Carnot en van der Waals. Op andere gebieden is zulk onderzoek pas de laatste jaren mogelijk geworden, doordat er speciale lasers en electronica beschikbaar kwamen. Binnen het bestek van deze rede is het onmogelijk u zelfs maar een elementair overzicht van al deze aspecten te geven.

Daarom heb ik gekozen voor een andere aanpak. Ik wil u een overzicht geven van de ontwikkelingen in een klein onderdeel van het vakgebied, dat ik meer dan twintig jaar heb gevolgd. Het betreft hier de pogingen om de schade te meten die het gevolg is van het welbekende hartinfarct. Zoals velen van $u$ weten, ontstaat zo'n hartinfarct doordat een kransslagader, of coronair-arterie, verstopt raakt. Hierdoor krijgt de hartspier plaatselijk geen bloed en zuurstof meer toegevoerd en worden schadelijke afvalstoffen niet meer verwijderd. Zelfs als zo snel mogelijk wordt ingegrepen, gaat meestal toch een deel van de hartspier verloren. De omvang van dit afgestorven deel wordt aangeduid als de 'infarctgrootte' en die zouden we graag precies willen meten. Ik zal $u$ in enig detail 
proberen te schetsen hoe het staat met de vooruitgang op dit beperkte gebied.

Van die beperking wil ik echter gebruik maken om een vergelijking tc maken tussen de ontwikkelingen zoals zc zich echt voltrekken en de gang van zaken zoals beschreven door de geldende wetenschapstheorie. Ik ga er daarbij vanuit dat het reilen en zeilen van de wetenschap als geheel u meer zal boeien dan de details uit een specialistisch declgebied. Om zo'n vergelijking mogelijk te maken moet ik cerst een kort uitstapje maken naar de beschrijving van het verschijnsel wetenschap.

\section{Wetenschap en paradigma.}

Een vakgebied als de natuurkunde is oud en gerespecteerd, en dat geldt ook voor de wiskunde, de sterrenkunde en de scheikunde. Dit respect straalt af op de vakken die zich op deze disciplines baseren, zoals de biologic en de geneeskunde. Gezamenlijk worden deze vakgebieden vaak aangeduid als de natuurwetenschappen, en hun wetenschappelijke status verschilt duidelijk van wat men de cultuurwetenschappen nocmt: taal- en letterkunde, geschicdenis, rechten, theologie, sociologie en psychologie. Een vergelijking van wat er onlangs in de media is verschenen over de psycholoog Dickstra, die jarenlang plagiaat pleegde, en de chemicus Buck, die ten onrechte stelde een middel tegen aids te hebben gevonden, laat in dit verband interessante verschillen zien. Het geval Buck werd afgedaan als persoonlijk falen, en verder was er kritick op de manier waarop zulk onderzoek wordt gefinancierd, omdat de onderzoeker daardoor wordt verleid om voortijdig successen te melden. Niemand leek het zelfs maar in zijn hoofd tc halen om Bucks vakgebied, de organische chemie, iets te verwijten. Maar de kritick op Diekstra uilte zich ook als kritiek op de psychologie. Zo werd er schande gesproken van het feit dat in dit vakgebied plagiaat jarenlang niet werd gesignaleerd. Wie de ingezonden brieven las kon constateren dat elke leek zich het recht lijkt aan te metcn om de wetenschappelijkheid van een discipline als de psychologie te 
beoordelen en te kritiseren. Een nog recenter voorbeeld is de discussie over het vakgebied volkskunde, naar aanleiding van Voskuils romancyclus 'Het Bureau' over het P. J. Meertensinstituut in Amsterdam.

Over dit verschil tussen natuur- en cultuurwetenschappen hebben velen zich het hoofd gebroken. Zo omschreef de Britse fysicus Charles Snow het als een tegenstelling tussen twee volledig gescheiden culturen [1]. Snow weet het bestaan van dic kloof vooral aan snobisme en behoudzucht van de cultuurwetenschappers, dic zouden weigeren om de vondsten van de natuurwetenschappen als culturele verrijking te zien. Als men Snows visie volgt, is het bijvoorbecld ongerijmd dat cen goede opvoeding nog stecds vereist dat men zich verdiept in de psychopathologie van cen wraakzuchtige Deense prins, terwijl men de hoofdwetten van de thermodynamica kan negeren.

Tegenover de mening vall Snow staan echter opvaltingen als die van de Frankfurter Schule, verwoord door de socioloog Jürgen Habermas [2]. Deze noemde het irreëel om te verwachten dat onze taal verrijkt zou moeten worden met atoom-poëzie of een spreekwoord over energicbchoud. Habermas stelde dat niet de culturele betckenis maar de practische gevolgen, en de daarmee verbonden macht, bepalen in hoeverre de naturwetenschappen lot het maatschappelijk bewustzijn doordringen. Door de komst van elektrisch licht, telefoon en televisic ontstond er ontzag voor de natuurkunde en dat ontzag werd versterkt door de angst voor een kernramp of de aantasting van de ozonlaag, want het zal u niet zijn ontgaan dat uw ijskast wel veilig is voor uzelf, maar niet voor de wereld.

Van de wetenschappelijke pogingen om dit verschil tussen natuur- en cultuurwetenschappen tc verklaren zijn vooral de idecën van de Amerikaan Thomas Kuhn bekend geworden [3]. Volgens Kuhn kan men pas over normale wetenschap spreken als er binnen een vakgebied sprake is van een paradigma. Deze term betekent zovecl als 'voorbecld' en 
duidt op een algemeen geaccepteerd begripskader waarmee resultaten worden beoordeeld, zodat men het kan gebruiken om zin van onzin te onderscheiden. Dit paradigma speelt zo'n centrale rol dat het niet meteen wordt verworpen als er tegenstrijdigheden opduiken. Eerder zal men aannemen dat er een onbekende factor in het spel is die de tegenstelling kan verklaren. Met deze opvatting verzette Kuhn zich tegen Poppers bekende falsificatietheorie [4] die stelt dat de wetenschap juist gericht zou zijn op het ontdekken van zulke tegenstrijdigheden, om zichzelf zo te corrigeren.

Als de bewijslast tegen het heersende paradigma echter te groot wordt, raakt de wetenschap volgens Kuhn tijdelijk in een revolutionaire fase, waarna een nieuw paradigma opduikt dat meer kan verklaren en weer algemeen wordt geaccepteerd. Vakgebieden die dit stadium van heersende paradigma's niet hebben bereikt, zouden zich in het vórwetenschappelijke of pre-paradigmatische stadium bevinden. In zo'n vakgebied ziet men een vruchteloze strijd tussen scholen met uiteenlopende uitgangspunten.

De wetenschap die volgens Kuhn het paradigmatische stadium illustreert is, u raadt het al, de natuurkunde. Een voorbeeld van een discipline die dat nog niet zou zijn is, u raadt het alweer, de psychologie. Met name in de Verenigde Staten heeft de kritiek op de oorspronkelijke ideeën van Freud bijna de vorm van een gezelschapsspel aangenomen en wordt psychoanalytische behande-ling wel aangeduid als "treatment of the id by the odd". Vooral het feit dat men bij zo'n behandeling niet alleen voor psychoanalyse kan kiezen, maar bijvoorbeeld ook voor voor gedragstherapie, die op geheel andere principes is gebaseerd, illustreert het pre-paradigmatische stadium. Daarbij komt nog dat het toenemend gebruik van psychofarmaca suggereert dat er ook een wél wetenschappelijke aanpak zou bestaan. Zo wordt ons zelfs in de reclame verteld dat Prozac de zenuwgeleiding vertraagt. Dat geeft velen kennelijk een gerust gevoel, maar men verliest daarbij uit het oog dat een vertraagde zenuwgeleiding ons 
even weinig kan vertellen over het ontstaan van een depressie, als een uitleg van de werking van ons gehoor ons duidelijk kan maken waarom wij van muziek genieten. Wat dit betreft kan de psychoanalyse ons aanzienlijk meer verklaren!

Hoewel Thomas Kuhn vooral wetenschappelijke vooruitgang wilde beschrijven, vroeg hij ook aandacht voor de tijdelijkheid van een geaccepteerde verklaring en voor het sociologische aspect in de natuurwetenschappen: de spraakmakende groep die elkaar kent van redacties en adviesraden en die uitmaakt wat wel of niet belangrijk is. Zo was een van Kuhns observaties dat bij de entree van een nieuw paradigma de aanhangers van het oude zich zelden laten overtuigen. Onlangs was ik getuige van zo'n paradigmatische aanvaring toen de psycholoog Crombach, hoogleraar aan deze universiteit, een toelichting gaf op zijn recente publicatie [5] waarin hij het bestaan ontkent van psychoanalytische begrippen als onderbewustzijn en verdringing. Alles wat hij in dit debat als argument naar voren bracht werd door de psychoanalytici in het gezelschap met welwillende ironie als irrelevant of als misverstand bestempeld. Toch merken de aankomende studenten, volgens Kuhn, dat het nieuwe paradigma meer mogelijkheden biedt, ook om carrière te maken, en zo zal de oude leer verdwijnen door het uitsterven van zijn aanhangers.

Vooral de laatstgenoemde ideeën van Kuhn hebben er zeker toe bijgedragen dat men realistischer over het verschijnsel wetenschap is gaan denken, maar toch heeft zijn indeling ook ongewenste gevolgen gehad. In de eerste plaats heeft de hoge status die werd toegekend aan de natuurwetenschappen geleid tot een soms overdreven ontzag voor alles wat zich in maat en getal laat uitdrukken. Dit heeft zeker geleid tot een onderwaardering van het niet-kwantitatieve en conceptuele in de wetenschap. Zo kon het gebeuren dat de historicus Immanuel Wallerstein zich in zijn magistrale werk over de opkomst van het kapitalistische systeem [6] moest verdedigen tegen de kritiek dat dit werk zinloos was, omdat 
deze historische ontwikkcling zich slcchts écnmaal hecft voorgedaan en de geldigheid van zijn idecën dus niet getoetst kan worden. Wallersteins tegenwerping dat onderzocht moet worden wat om opheldering vraagt $\mathrm{cn}$ nict wat zich prettig laat onderzoeken, was terecht en herinnert aan de man die onder cen lantaarn naar zijn fictsslcuteltjc zocht, nict omdat hij het daar verloren had maar omdat hij daar iets kon zien. Het zal duidelijk zijn dat het beter is om met onvolmaakte middelen, desnoods op de tast, te zocken naar wat ons echt verder kan bengen, dan geavanceerde methodick los te laten op het irrelevante, het modieuze of het triviale.

Zoals ik u hierna zal schetsen, is cen meer fundamentelc kritiek op Kuhn's idecën dat in de praktijk van het natuurwetenschappelijk onderzock centrale paradigma's nauwclijks een rol spelen. Zcker, iedereen neemt aan dat twee plus twee vier is, maar juist aan de grenzen van wat men weet - en daar speelt zich nu eenmal het onderzock af - vindt men richtingenstrijd, negeren van resultaten en verwarring. Kortom, daar vindt men, ook in de natuurwetenschappen, alle omstandigheden die Thomas Kuhn beperkt zag tot het preparadigmatische stadium. Zoals gezegd, zal ik proberen dit te illustreren aan de hand van de infarctgrootte, en daarom zal ik cerst uitleggen waarom men die wil meten.

Waarom men de grootte van cen hartinfaret wil meten.

Hart- en vaatzickten zijn in de westerse wereld de belangrijkste doodsoorzaak en men heeft daar tot voor kort weinig aan kumen doen. Pas vanaf de jaren vijftig en zestig kwamen er middelen beschikbaar om het ziekteproces dat tot het hartinfarct leidt te vertragen, o.a. door verlaging van de bloeddruk, bestrijding van ritmestoornissen, verlaging van het cholesterolgehalte in het bloed en remming van de bloedstolling. Ook leerde men hoe een catheter in een kransslagader kon worden gebracht, voor het inspuiten van een contrastmiddel zodat het blocdvat zichtbaar werd op cen röntgenbeeld. Zo kan men een dreigende vernauwing vroeg- 
tijdig opsporen en met de catheter het bloedvat oprekken, het bekende 'dotteren'. Daarnaast kwam de hart-long machine beschikbaar, die tijdclijk de functic van deze organen kan overnemen zodat men het hart stil kan leggen om er een operatie op uit te voeren, een 'coronaire bypass' operatie bijvoorbeeld, waarbij men een bloedvat implanteert dat het bloed om de afgesloten plek heen leidt.

De hier genoemde preventieve technieken, met name het dotteren en de coronaire bypass operatie, worden bovendien gebruikt om in patiënten die toch een hartinfarct krijgen de bloedstroom zo snel mogelijk te herstellen. Maar op dit gebied is vooral de behandeling met 'thrombolytica' bclangrijk, stoffen waardoor het afsluitende bloedstolsel wordt afgebroken, zodat de bloedstroom weer op gang komt. De laatste dertig jaar is de sterfte aan het hartinfarct dan ook voortdurend gedaald. Anders dan vaak gedacht wordt - met name door mensen die gestopt zijn met roken en dagclijks hun rondjes lopen! - blijkt die daling voor zo'n $75 \%$ het gevolg van dezc nieuwe behandelingsmogelijkheden en maar voor $25 \%$ van een gczondere levenswijze [7].

Met het ontstaan van mogelijkheden om te behandelen, groeide ook de behoefte om het effect daarvan tc bewijzen. Het meest overtuigende bewijs is natuurlijk dat men kan laten zien dat door de behandeling minder mensen overlijden. Daarbij is echter een groot probleem dat de patiënten meestal overlijden vo6rdat het ziekenhuis wordt bereikt en er van behandeling sprake kan zijn. Van de patiënten met een hartinfarct die het ziekenhuis levend bereiken sterft in cen moderne hartbewakingsafdeling minder dan $5 \%$. Als men deze sterfte met $20 \%$ weet te beperken - wat als een aanzienlijk therapeutisch succes wordt beschouwd - betekent dit dat er per honderd patiënten geen vijf maar vier overlijden. Maar zo'n resultaat kan natuurlijk ook op tocval berusten en om zeker tc zijn dat dit niet $z o$ is moet men dus grote aantallen patiënten behandelen.

Dal is dan ook precies wat tegenwoordig gebeurt. In inter- 
nationale mega-trials wordt zo'n behandeling in soms honderden ziekenhuizen op tienduizenden patiënten toegepast $[8,9,10]$. Het zal duidelijk zijn dat de hieraan verbonden kosten enorm zijn en dat het vaak jaren duurt voordat zo'n studie is afgerond. Waarom volgt men deze kostbare en omslachtige weg? Waarom wordt niet eenvoudig in alle patiënten de infarctgrootte gemeten en laat men zien dat die door de behandeling is afgenomen? Men zou dan ook de grote meerderheid van overlevende patiënten bij de meting kunnen betrekken, zodat een effect van de behandeling veel eerder zou blijken.

Het zou natuurlijk kunnen zijn dat er geen geschikte methode bestaat voor het bepalen van de infarctgrootte, of dat de infarctgrootte weinig zou zeggen over de kans op overlijden na een hartinfarct. Het tegendeel is echter waar! Er bestaat zelfs een aantal van zulke bepalingsmethoden en sommige daarvan kunnen vrijwel zonder overlast voor patiënten worden uitgevoerd. Ook werd aangetoond dat de zo gemeten infarctgrootte een goede voorspelling geeft van de kans op overlijden en blijvende invaliditeit, en dat zo'n meting goed overeenkomt met de hoeveelheid afgestorven hartspierweefsel zoals die kan worden bepaald in harten van overleden patiënten.

Nee, de echte oorzaak van deze situatie is dat er ondanks vele studies, demonstraties en bewijzen, geen methode bestaat die algemeen wordt geaccepteerd. Om in de termen van Thomas Kuhn te spreken: meting van de infarctgrootte heeft het paradigmatische stadium nog niet bereikt. Elke methodiek heeft zijn eigen aanhangers, maar wordt door anderen niet vertrouwd. Het optimistische gezegde uit de natuurwetenschappen 'meten is weten' blijkt niet op te gaan. Meten is kennelijk slechts weten in beperkte kring!

Het is in feite nog erger, want men is het er zelfs niet altijd over eens wanneer hartspierweefsel dood of levend moet worden genoemd. Zoals ik nu zal uitleggen komt dat vooral door de vele manieren waarop het hart wordt bestudeerd. 


\section{De vele oorzaken van celdood.}

Het hart is een pomp die de bloedstroom naar de weefsels op gang houdt. Ik ben me ervan bewust dat deze kale definitie niet strookt met wat u voelt dat uw hart betekent, evenmin als de 'geheimen' in de titel van deze voordracht dezelfde zijn als die waaraan Pascal in de $17 \mathrm{e}$ eeuw dacht. Toch zou ik cven bij deze versmalde definitie van het hart willen blijven, ondat we dan ook de infarctgrootte kunnen definiëren als de afname van de pomp-functie.

Helaas! Deze definitie helpt ons niet echt verder. Het blijkt dat hartspicrcellen bij zuurstofgebrek al heel snel niet meer samen-trekken, dus ook nict meer bijdragen aan de pompfunctie, maar dan nog lang niet dood hoeven te zijn. Als men de bloedstroom naar het getroffen gebied herstelt, kunnen zulke cellen na enkele uren tot dagen, soms zelfs na maanden, weer gaan werken. Bovendien blijkt al binnen enkele uren na de uitval van cen decl van de hartspier dat de contractiekracht van het resterende deel toenecmt, zodat ook de pompfunctie weer verbetert. Er bestaat dus gecn enkel moment waarop men de afname van de pompfunctic direct kan relateren aan de hoeveelheid afgestorven hartspiercellen, d.w.z. aan de infarctgrootte.

Uit dit voorbeeld blijkt dat het contracticvermogen van cen spiercel geen goed criterium is om vast te stellen of de cel is afgestorven. Om betere kenmerken te vinden zouden we meer moeten weten over de oorzaken van het afsterven. Hierover blijken echter een groot aantal rivaliserende theorieen te bestaan. Zonder naar volledigheid te streven, wil ik u enkele van deze theoricën noemen.

Volgens de oudste theoric sterft de hartspiercel aan energiegebrek. Door het zuurstoftekort stopt de productie van energierijke verbindingen, zoals het adenosine-trifosfaat of ATP. De spiercel heeft niet alleen ATP nodig om arbeid te verrichten maar ook om de stoffen op te bouwen die nodig zijn oin de cel in stand te houden. Volgens deze theoric sterft de 
hartspiercel zodra de hoeveclheid ATP tevecl daalt.

Volgens een tweede theoric zouden hartspiercellen sterven door osmotische overbelasting. Osmose is een fysisch verschijnsel dat al in de $18 \mathrm{c}$ ceuw werd ontdekt, zoals wel vaker door cen monnik met belangstelling voor wijn. Deze monnik merkte dat de wijn dic hij in leren zakken in een vochtige kelder bewaarde stecds wateriger ging smaken. Door de grote hoeveelheid stoffen die de wijn bevat wordt water uit de omgeving aangetrokken. Op dezclfde manier zou er door ophoping van afvalstoffen in de bedreigde hartspiercel siceds meer water binnendringen, totdat de cel bezwijkt.

Een derde theorie over celdood richt zich op de celmembraan, een dun vliesje van zogeheten 'fosfolipiden', dat de cel omgeeft en van de buitenwereld afschermt. Als de hoeveelheid calcium in een cel stijgt, bijvoorbecld doordat die wegens ATP-gebrek nict meer naar buiten wordt gepompt, leidt dat tot activatie van z.g. 'fosfolipases', ciwitten dic in staat zijn om fosfolipiden af te breken. Als dic afbraak de aanmaak van nieuwe fosfolipiden overtreft, kan de membraan niet in stand blijven en zal de cel afsterven.

Een vierde theoric ziet de 'vrije radicalen' als de boosdoeners. Vrije radicalen zijn stoffen die tijdens de stofwisseling gevormd worden, maar die uiterst reactief zijn. Daarom bevat de cel een aantal mechanismen waarmec zc onschadelijk worden gemaakt. Met name bij 'reperfusie-therapie', als de verstopte kransslagader weer tocgankelijk wordt gemaakt voor vers blocd met zuurstof, ontstaat er een golf van vrije radicalen. Deze zouden de membraan aantasten en zo celdood veroorzaken.

Een hartspiercel is geen homogeen blaasje omgeven door de celmembraan, maar een ingewikkelde structuur. Zo bevat de cel een netwerk van eiwit-draden die verankerd zijn in de membraan en het skelet van de cel vormen. Mede door de stijging van de hoevcclheid calcium, worden z.g. 'proteases' geactiveerd. Dat zijn ciwitten die in staat zijn om andere ciwitten af te breken en zo ook het celskelet aan te tasten. 
Volgens een vijfde theoric is dic antasting de oorzaak van het afsterven van de cel.

Een zesde oorzaak van ccldood is de 'apoptose', het Grickse woord voor het afvallen van bladeren in de herfst. Het was al lang bekend dat bij dc ontwikkcling van een embryo bepaalde cellen maar korte tijd anwezig zijn, om daarna weer te verdwijnen. Voor dit verdwijningsproces is onlangs ook interesse ontstaan in de kringen die de hartspier bestuderen. De cel blijkt een genctisch vastgelegd programma te bezitten waarmee zij zichzelf als het ware uitschakelt en geruisloos afsterft.

De hierboven beschreven theoricën gaan uit van mechanis-men dic vanuit het inwendige van de cel werken. Daarnaast bestaan er theorieën dic uitgaan van aantasting van buitenaf. Zo worden cr blocdeiwitten geactiveerd, de z.g. complement-factoren, die in staat zijn om gaten in de membraan te vormen. Ook zou de hartspiercel worden aangevallen door de witte blocdecllen dic normaal onze afweer tegen bacteriën verzorgen.

Ik kan mij voorstellen dat het $u$ na deze zevende en achtste theorie over celdood een beetje begint te duizelen, en dat is ook precies het gevoel dat onderzoekers in dit vakgebied ondervinden. Ik wil met dezc verwarrende opsomming ook niet suggereren dat vecl van dit onderzoek slecht of overbodig zou zijn. Het gaat immers om verschijnselen die allemaal tegelijk optreden, zodat het buitengewoon moeilijk is om vast te stellen wat oorzaak en gevolg is. Hopelijk zullen we in een niet al te verre toekomst in staat zijn om te zien dat veel van dit onderzoek slechts op bijverschijnselen was gericht, maar op dit moment weet nog nicmand voor welke studies dat geldt.

Het is echter wél mijn bedoeling om u te laten zien dat men hier alle verschijnselen kan waarnemen die Thomas Kuhn noemt voor een wetenschap in het pre-paradigmatische stadium. In de eerste plaats is dat het modieuze karakter. Honderden publicaties over ATP-uitputting werden gevolgd door honderden over membraanafbraak. En, om even bij dit 
modebeeld te blijven, daarna kwamen de korte rokken van de vrije radicalen en het décolleté van het celskelet, terwijl op dit moment alles wordt bedekt met de mantel van de apoptose. Als een onderzoeker in $z^{\prime} n$ periode vergeet de juiste modeontwerpers en kleding in zijn subsidieaanvragen te noemen, heeft hij zelf al snel niets meer om aan te trekken.

Een ander typerend aspect is het niet kennen, het negeren of wegpraten van resultaten die strijdig zijn met de favoriete hypothese. Men kan bijvoorbeeld laten zien dat er $66 \mathrm{k}$ celbeschadiging optreedt als men het bloed dat door het hart stroomt vervangt door een zoutoplossing, warin geen witte bloedcellen aanwezig zijn. Aanhangers van de theorie dat juist díe cellen de schade veroorzaken redden zich hier echter uit door te stellen dat spoelen met zo'n oplossing geen natuurlijke situatie is en dat daaruit dus ook geen conclusies mogen worden getrokken. En daar zit misschien ook best iets in!

Twijfel aan de waarde van gepublicecrde resultaten wordt trouwens in de naturwetenschappen een steeds algemener verschijnsel. In een tijd waarin men van achter zijn bureau direct in verbinding staat met alle grote bibliotheken en literatuurbestanden, blijkt er juist sprake te zijn van een toenemend wetenschappelijk informatieverlies en een toenemende scepsis ten aanzien van wat wél wordt gelezen. De steeds verder opgevoerde publicatiedruk en de noodzaak om voor financiering van het onderzoek internationaal aandacht te trekken, hebben een toestand veroorzaakt waarbij zelfs in vooraanstaande bladen als Nature en Science artikelen verschijnen die al binnen enkele maanden moeten worden herroepen omdat ze op knullige fouten blijken te berusten. En dan gaat het nog niet eens om de ook steeds vaker gesignaleerde regelrechte fraude in de wetenschap.

Geen wonder dat het onder die omstandigheden gemakkelijker wordt om onwelkome berichten te negeren. Maar dat verschijnsel is al oud en heeft misschien niet alleen negatieve aspecten. Daar waar dieper op de geschiedenis van weten- 
schappelijke vondsten wordt ingegaan blijkt dat, na de fase van onbevangen observatie waarin het idee ontstaat, soms een fase nodig was waarin de onderzoeker oogkleppen droeg. Zo zijn de wetten van Mendel [11] en de ontdekking van het eiwit prothrombine [12] voorbeelden van vondsten waarbij sommige waarnemingen wel moesten worden genegeerd om in het resultaat te blijven geloven.

Misschien hebt $u$ op op dit voorbeeld van wetenschappelijke verwarring rond het begrip celdood wel de kritiek dat nu juist de begrippen leven en dood niet streng natuurwetenschappelijk gedefinieerd kunnen worden. Mag men 'prionen', de verwekkers van de dolle-koeien ziekte, levend noemen? Waarschijnlijk gaat het daarbij om eiwitten met een afwijkende vorm die in staat zijn om soortgelijke eiwitten, die een koe van nature bezit, van hun normale vorm te doen overgaan in de afwijkende vorm. Prionen kunnen zichzelf dus vermenigvuldigen en dat wordt als een belangrijk criterium voor leven beschouwd. Ooit heeft de dichter-bioloog Leo Vroman de vraag of men een eiwit levend mag noemen, volmondig met ja beantwoord toen hij bij de dood van een meisje de volgende regels schreef [13]:

Slechts haar inhoud leefde zacht

en hopeloos nog een uur of acht

Pas zo'n acht uur na de dood hebben veel eiwiten hun oorspronkelijke vorm verloren en pas dan beschouwt Vroman ze als dood. Maar de meeste biologen hebben er moeite mee om eiwitten levend te noemen, voornamelijk omdat ze geen erfelijk materiaal bevatten.

Om $u$ echter te tonen dat de verwarring niet werd veroorzaakt door dit fundamentele probleem van leven en dood wil ik $u$ iets vertellen over de ontwikkeling van é́n van de praktische methoden om de infarctgrootte te meten. 
Meting van de infarctgrootte m.b.v. markecr-eiwitten.

Deze methode makk gebruik van eiwitten dic normal alleen binnen de cel voorkomen. In 1954 werd ontdekt dat bij het afsterven van hartspiercellen de celmembraan lek wordt zodat de eiwitten naar buiten kunnen en in het bloed terechtkomen [14]. Door de hocveelheid van zo'n markecreiwit in het bloed te meten zou men moeten kunnen schatten hoeveel cellen zijn afgestorven.

Het zal u na het voorafgaande niet verbazen dat over de fundamentele vraag of de uitstorting van deze eiwitten door een cel ook werkelijk betekent dat de cel dood gaat, geen overeenstemming bestaat. Volgens sommige onderzoekers kan de hartspiercel allang dood zijn zonder dat er ciwitten uit weglekken, volgens anderen kan de cel ciwitten verliezen zonder dood te zijn. In de praktijk laat men deze vraag dan ook voor wat ze is en concentreert men zich op methoden om de totale uitstorting van markecreiwitten in het bloed te meten.

Wil men zo'n uitgestorte hoevcelheid ciwit relateren aan de infarctgrootte, dan moeten alle mensen per gram hartspierweefsel ongeveer dezelfde hoeveelheid van zo'n eiwit hebben. Bij gezonde harten, bijvoorbceld afkomstig van verkeersslachtoffers, blijkt dat ook zo te zijn en varieert de hartinhoud van deze eiwitten maar zo'n 10 tot $15 \%$. Dat is echter anders voor de zieke harten van mensen die een hartinfarct krijgen. Dergelijke harten blijken tot wel $80 \%$ minder eiwit te bevatten. De spiercellen zélf zouden minder eiwit kunnen bevatten, maar er kan ook sprake zijn van een soort verdunning, waarbij vrijwel normale spiercellen worden verdund met bindweefsel en vet. Alleen in het laatste geval kan men de hoeveelheid uitgestort markeereiwit toch nog relateren aan de hoeveelheid afgestorven spiercellen.

Een volgende vraag bij deze methodick is of alle eiwitten die oorspronkelijk in de spiercellen aanwezig waren ook werkelijk in het bloed terecht komen. Eiwitmoleculen zijn namelijk zo teer als vlinders en het is goed denkbaar dat ze dit transport niet overleven. In de jaren zeventig leken studies in 
honden aan te tonen dat er inderdaad gemiddeld maar zo'n 15 $\%$ in het bloed terecht kwam [15]. Dat was een alarmerend getal want, vertaald naar patiënten, zou dat bij de ene patiënt natuurlijk best $10 \%$ cn bij een andere patiënt wel $20 \%$ kunnen zijn, wat een fout van cen factor twee in de geschatte infactgrootte zou betckenen! Onderzock aan deze universiteit heeft echter een aantal fouten in deze vroegere studies aangetoond en lijkt crop te wijzen dat vrijwel alle eiwitten in het bloed terechtkomen [16].

Ik heb nu de cerste dric fundamentele vragen bij de tocpassing van deze methode genocmd: 1) Bctckent eiwitverlics dat de hartspicrcel afsterft? 2) Bevatten hartspiercellen steeds dezelfde hoeveelheid eiwit? en 3) Komen de eiwitten uit afgestorven cellen volledig in het bloed terecht? Over het antwoord op geen van deze vragen blijkt overeenstemming te bestaan. En er moeten nog andere vragen worden beantwoord. Zo moet de snclheid waarmee zo'n eiwit uit het bloed verdwijnt worden geschat, evenals de hoeveelheid eiwit die zich buiten de bloedbaan bevindt. Het zal u niet verwonderen dat op deze punten de meningen opnieuw heftig botsen.

Gezien al deze onzekerheden zult $u$ misschien denken dat het meten van markeer-eiwitten in het bloed bij patiënten met een hartinfarct nauwelijks zal gebeuren. Immers, wat hebben we aan een grootheid waarvan zowel de biologische betekenis als de kwantitatieve uitslag op losse schroeven staan? Het tegendeel is echter het geval! In de klinische praktijk bleken ze goede indicatoren voor de diagnose en de prognose van het hartinfarct, zodat de meting van deze eiwitten al binnen enkele jaren na de ontdekking in 1954 tot de standaardmethoden in de hart-bewakingsafdeling is gaan behoren. Met name de ciwitten troponine $T$ en troponine I worden de laatste jaren zelfs gebruikt om onderscheid te maken tussen patiënten waarbij nog net geen hartspiercellen afsterven, en patiënten waarbij dat toch gebeurt. Het is namelijk gebleken dat zelfs zo'n geringe celdood de prognose aanzienlijk verslechtert [17], zodat men cerder zal overgaan 
tot een dotterbehandeling of een bypass-operatie. Theorie en praktijk hebben hier blijkbaar nauwelijks iets met elkaar te maken!

Concluderend kunnen we zeggen dat noch op het gebied van een fundamenteel proces als celdood, noch op het gebied van praktische meetmethoden, zoals voor de meting van de uitstorting van markeereiwitten in het bloed, wetenschappelijke concensus of zels maar wetenschappelijk vertrouwen bestaat.

\section{Conclusies.}

Wat moeten we hier nu mee? Bestaan er dan ook in de naturwetenschappen geen echte waarheden, geen echte vooruitgang? Wie een uurtje nadat hij in Schiphol is opgestegen op zijn vakantiebestemming aankomt, of wie met een hartinfarct op de bewakingsafdeling terecht komt, ziet de vooruitgang toch meteen!

Ja, maar wat was daarin het aandeel van de officiële wetenschap? Auteurs als Snow en Habermas hebben al opgemerkt dat dit soort veranderingen vooral via verbeterde technologie tot stand komen, waar de wetenschap dan achteraan lijkt te hobbelen. Henry Ford was zonder opleiding in de naturkunde bezig met auto's en de gebroeders Wright gebruikten hun eigen gewicht om te zien of hun vliegtuigen voldoende draagkracht hadden. De stoommachine werd uitgevonden door de instrumentmaker James Watt en pas nadat de natuurkundige Sadi Carnot die machine grondig had bestudeerd, kon hij de omzetting van warmte in arbeid wetenschappelijk beschrijven. Zoals Lawrence Henderson opmerkte: de wetenschap heeft meer te danken aan de stoommachine dan de stoommachine aan de wetenschap.

Om een recenter voorbeeld te noemen: de transistor werd eind jaren veertig ontdekt toen technici van Bell's Telephone Company elektrische stromen door halfgeleiders lieten lopen. Hierdoor werd de computer- en informatietechnologie mogelijk die een ware maatschappelijke omwente- 
ling hebben veroorzaakt. Toen ik twintig jaar na deze ontdekking afstudeerde in de theoretische natuurkunde, werden transistors al volop gebruikt maar de theorie daarvan werd op ons instituut nog niet behandeld. Wat op dat gebied in de kwantummechanica aan 'gatentheorie' was ontwikkeld, werd door de theoretische fijnproevers beschouwd als broddelwerk, goed voor practica en technici.

Maar niet alle theoretici leven in ivoren torens en hoewel we dus meer in een technologische dan een wetenschappelijke wereld leven, bestaat er natuurlijk toch wisselwerking tussen theorie en praktijk. Soms wordt er wel degelijk wetenschappelijke vooruitgang geboekt die nieuwe technologie mogelijk maakt. In de vorige eeuw gebeurde dat toen Maxwell zijn vergelijkingen voor electromagnetische velden publiceerde. In deze eeuw toen Watson en Crick de structuur van het DNA vonden. Zoals beschreven door Thomas Kuhn vallen op zo'n moment vele stukjes van een puzzel op hun plaats en erkent het vakgebied de vooruitgang snel, d.w.z. binnen én generatie. Echter, ook de culturwetenschappen kennen zulke belangrijke momenten. Freud's ideeën over de invloed van jeugdervaringen op de persoonsontwikkeling, Marx' ideeën over de invloed van economische factoren op het maatschappelijk bestel en Chomsky's theorie over het aangeboren taalvermogen, hebben ook de weg naar nieuwe praktische toepassingen geopend.

Ik wil dit overzicht dan ook afsluiten met de stelling dat het misverstand van de superieure paradigmatische natuurwetenschappen is ontstaan doordat mensen als Snow, Kuhn en Popper natuurkundigen waren en doordat ze uiterst zeldzame momenten in hun vakgebied hebben gebruikt als model voor de normale gang van zaken.

\section{Dankwoord.}

Zoals gebruikelijk wil ik deze rede afsluiten met een dankwoord aan de personen en instanties die mijn benoeming mogelijk hebben gemaakt. 
In de eerste plaats richt ik mij daarbij tot het College van Bestuur en het Bestuur van de Faculteit der Genecskunde van de Universiteit Maastricht. In 1977 werd an dezc universiteit de commissie ingesteld voor mijn benocming als bijzonder hoogleraar moleculaire biofysica. Begin dit jaar ontving ik mijn benoemingsbrief als bijzonder hoogleraar in de moleculaire fysica. Sommigen van de hicr aanwezigen zullen zich misschien afvragen of men zich in dit voormalige Jezuictenklooster, waarin men zich nu bevindt, met theologische hardnekkighcid gedurende deze twintig jaar het hoofd hecft gebroken over de viaag of hel voorvocgsel 'bio' in mijn lceropdracht mocst worden geschrapt. De warheid gebiedt echter te zeggen dat hoogleraarsbcnocmingen zich niet altijd paradigmatisch voltrekken. Gelukkig leven wij echter in ecn land waarin beginnende universiteiten, bij hun ecrste wankele schreden op dit gebicd, van hogerhand kunnen worden begeleid en gecorrigeerd. Onder deze omstandigheden rest mij dan ook niet anders dan u te danken voor het vertrouwen dat $\mathrm{u}$ in $\mathrm{mij}$ heeft moeten stcllen.

Het Bestuur van de Stichting Wetenschapsbeoefening Universiteit Maastricht wil ik danken voor het financieel mogelijk maken van deze benoeming.

Hooggeleerde Hemker, beste Coen. Toen ik als pas afgestudeerd fysicus begon op de afdeling Cardiologie in Leiden, was het me al snel duidelijk dat ik voor de muzick in het wetenschappclijk bedrijf op jouw afdeling mocst zijn. Met name heb je toen meteen mijn belangstclling gewckt, zowel voor het ellipsometrisch onderzoek van de blocdstolling, warover ik door tijdsgebrek vandaag niets heb kunnen zeggen, als voor de bepaling van de infarctgrootle. Het getuigt van jouw wetenschappelijke visic dat ik nu, bijna dertig jaar later, nog stecds op beide gebieden werkzaam ben en bovendien het gevoel heb daar nog een evenlange periode vruchtbaar mee bezig te kunnen blijven. Behalve voor deze initiatic ben ik je ook dankbaar voor je voortdurende belangstelling gedurende al die jaren. 
Zeergeleerde Wittevcen, beste Jacques. Toen wij elkaar in 1969 bij de lift van het oude gebouw Interne Geneeskunde in Leiden leerden kennen, vertelde je aan cen onderzock te beginnen waarbij bloedmonsters van patiënten met een hartinfarct werden onderzocht op hun gehalte aan harteiwitten. Weinig kon ik toen vermoeden dat ik bij dat onderzock zou worden betrokken en dat het zou leiden tot de eerste klinische schatting van de grootte van cen hartinfarct. Veel ecrder dan ik heb jij begrepen dat praktische ontwikkelingen in de cardiologic meer gewicht in de schaal leggen dan theoretische onderbouwingen, maar zoals uit deze rede mogen blijken is dat bescf nu ook bij mij ontstaan.

Hooggeleerde van der Laarse cn hooggeëerde Hollaar, beste Arnoud en Lenie. Onze gemeenschappelijke wortels lagen op de afdeling Cardiologic in Leiden en lange jaren na ons vertrek naar Maastricht is ons onderzoek ook hecht verbonden gebleven. Uiteraard werden daarbij op den duur ook verschillende paden ingeslagen, maar het heeft nooit lang geduurd voordat wij wederzijds het landschap en de vergezichten op deze nicuwe paden kwamen bewonderen. Het is mijn oprechte wens dat deze warme wetenschappelijke en persoonlijke belangstelling ook in de toekomst zal voortduren.

Zeergeleerde Willems, beste George. Lang hebben wij intensief samengewerkt en vecl van mijn wetenschappelijke inzichten zijn mede te danken aan jouw inspanningen en talenten. Misschien was onze samenwerking wel al te nauw. Als men erg dicht op elkaar zit, neemt met het klimmen der jaren het vermogen af om elkaar nog scherp te zien, en als men in zo'n positie probeert om zich samen over het werk tc buigen, kan men elkaar gevoelig voor het hoofd stoten. Daarom is het goed dat jij je nu meer bent gaan richten op het ellipsometrisch uitdiepen van oppervlakteverschijnselen, terwijl ik blijf proberen de infarctgrootte klein te krijgen.

Hooggeleerde van Dieijen, zecrgeleerde Glatz, zeergeleerde de Zwaan en zeergeleerde Maessen, beste Marja, Jan, Chris en Jos. Op het gebied van cardiale markecreiwitten heeft 
zich tussen ons een intensieve samenwerking ontwikkeld die, zoals onlangs bleek bij het 50 -jarige bestaan van de Nederlandse Vereniging voor Klinische Chemie, 'Maastricht' een speciale positie heeft bezorgd. Het geeft mij een bijzondere voldoening dat ik vanaf 1977, als begeleider van Marja's promotieonderzoek, aan de wieg heb gestaan van deze ontwikkeling. Er staan spannende zaken te gebeuren, zowel wat betreft de invloed van ontstekingsremming op de infarctgrootte, als wat betreft het gebruik van nieuwe markeereiwitten zoals het fatty acid-binding protein, dat vooral door Jan's werk ons aller troetelkind is geworden. Ik kan mij nu al verheugen op ons gezamenlijke werk van de komende jaren.

Hooggeleerde Hack, hooggeleerde Aarden en zeergeleerde Strengers, beste Erik, Lucien en Paul. Een van de beste dingen die mij wetenschappelijke zijn overkomen is de intensieve samen-werking die zich de laatste jaren tussen ons heeft ontwikkeld. Vooral Erik's aanstekelijke enthousiasme heeft daarbij zoveel projecten en resultaten opgeleverd dat ik mijn schuldgevoel alles niet op tijd gepubliceerd te krijgen als enige smet op onze samenwerking beschouw. Dat het Centraal Laboratorium van de Bloedtransfusiedienst in Amsterdam bereid is om de komende jaren een enorm bedrag te investeren in de eerste klinische poging om door complementremming de infarctgrootte te beperken, is vooral aan jullie te danken.

Zeergeleerde Kleine, zeergeleerde Speijer en zeergeleerde Robers, beste Appie, Han, en Markus. Jullie hebben de laatste jaren in operatiekamers en laboratoria het werk verricht waaruit de nieuwe inzichten worden geboren. Het behoort tot de onrechtvaardigheden des levens dat, net als in dit dankwoord, toch eerst de mensen worden bedankt die dat materieel mogelijk hebben gemaakt. In de huidige wetenschap zitten beheerders nu eenmaal in grotere kamers dan onderzoekers en de enige troost is dat onderzoeken een stuk leuker is dan beheren. In mijn gedroomde onderzoeksinstituut, een wit gebouw in groene bossen, zouden jullie alle 
drie een grote kamer krijgen.

Beste Marie-Louise en Bernadette. Onze samenwerking is zonder titulatur en formaliteiten. Jullie vormen de ruggegraat van mijn dagelijkse werkomgeving en ik wil jullie, behalve daarvoor, ook danken voor de enorme hoeveelheid werk die jullie in de loop der jaren hebben verzet. Als ik een dia van zes behandelde en zes onbehandelde honden laat zien, beseft maar een enkeling dat zo'n plaatje driekwart jaar laboratoriumwerk representeert. Hetzelfde geldt voor de meting van markeereiwitten in zelfs maar een kleine trial van een paar honderd patiënten. Alleen op deze manier kan men uitleggen wat het betekent dat het onderzoek tientallen harten en duizenden patiënten omvatte.

Hoewel het werk vandaag de nadruk krijgt is het tot slot goed om stil te staan bij datgene wat nodig was om te kunnen werken. In de eerste plaats dank ik daarvoor mijn moeder die vandaag gelukkig hier aanwezig kan zijn. Helaas kan mijn vader deze dag niet meer meemaken. Hij zou er zeker van hebben genoten. Hoewel mijn ouders altijd als vanzelfsprekend verwachtten dat mijn zusje en ik zouden werken en studeren, hebben ze ons ook altijd laten zien dat genieten minstens zo belangrijk is. De waarde van die les, en vooral ook de zeldzaamheid daarvan, ben ik steeds meer in gaan zien.

$\mathrm{Er}$ is waarschijnlijk niets wat minder paradigmatisch verloopt dan de dagelijkse samenleving tussen twee mensen. Ook het principe van elke innige relatie, elkaar zo min mogelijk te kwetsen, lijkt geen praktische leiddraad. Immers, als men dit steeds bewust moest proberen, zou de ontroering waaruit het vanzelf moet voortkomen er niet meer zijn. Nee, het lijkt allemaal improvisatie en dromerij, soms gestuit door Elsschots wetten en bezwaren, en door weemoedigheid die des avonds komt, zodat men niet meer kan vertalen. En Fieke, vertalend aan dezelfde tafel, af en toe foeterend op die onzinnige nieuwe spelling, heeft aan alles bijgedragen, ook aan wat ik heb gezegd. 


\section{Literatur.}

1. C.P. Snow. The two cultures. Cambridge University Press, Cambridge 1959.

2. J. Habermas. Technik und Wissenschaft als 'Ideologie'. Suhrkamp, Frankfurt 1968.

3. T.S. Kuhn. The structure of scientific revolutions. International Encyclopedia of Unified Science. Volume 2, Numer 2, The University of Chicago Press, Chicago 1962.

4. K.R. Popper. Conjectures and refutations. The growth of scientific knowledge. Routledge \& Kegan Paul Limited, London 1963.

5. H.F.M. Crombach en H.L.G.J. Merckelbach. Hervonden herinneringen en andere misverstanden.Uitgeverij Contact, Amsterdam 1996.

6. I. Wallerstein. The modern world-system. Academic Press. New York 1974.

7. M.G.M. Hunink e.a. The recent decline in mortality from coronary heart disease, 1980-1990. The effect of secular trends in risk factors and treatment. JAMA 1997: 277: 535-42.

8. GISSI (Gruppo Italiano per. 10 studio della streptochinasi nell'infarto miocardico): Effectiveness of intravenous thrombolytic treatment in acute myocardial infarction. Lancet 1986; i; 397-402.

9. ISIS-2 (Second International Study of Infarct Survival) collaborative group: Randomized trial of intravenous streptokinase, oral aspirin, both, or neither among 17187 cases of suspected acute myocardial infarction: 1SIS2. Lancet 1988; ii; 349-60.

10. The GUSTO Investigators: An international randomized trial comparing four thrombolytic strategies for acute myocardial infarction. N Engl J Med 1993; 329: 673-82.

11. W.F. Kruit. DNA, de kern van het leven. Hogeschool Amsterdam, Amsterdam 1996.

12. hr. W. Hemker. De ontdekking van het prothrombine. Proefschrift. Maastricht 1981.

13. L. Vroman. Pijn en het meisje. In: Gedichten, Querido, Amsterdam, 1974.

14. J.S. LaDue e.a. Serum glutamic oxaloacetic transaminase activity in human acute transmural infarction. Science 1954; 120: 497-9. 
15. R. Roberts e.a. An improved basis for enzymatic estimation of infarct size. Circulation 52: 743-54, 1975.

16. W.Th. Hermens e.a. Complete recovery in plasma of enzymes lost from the heart after permanent coronary artery occlusion in the dog. Circulation 1990; 81: 649-659.

17. Ch.W. Hamm e.a. The prognostic value of serum troponin $T$ in unstable angina. $N$ Engl J Med 1992; 327: 146-50. 